\title{
Psychological Well-Being as a Correlate of Physical Well-Being among the Spouses of Indian Armed Force Personnel
}

\author{
Bisht Prachi ${ }^{1 *}$, Pande Lata ${ }^{2}$
}

\section{ABSTRACT}

Armed force is an organization where the process of deployment of soldiers or military personnel occurs very frequently. The soldiers are frequently deployed in either active field areas, high altitude areas and routine exercise because of which the families has to face separation for longer as well as for short duration influencing them emotionally, psychologically and mentally leading to stress responses, such as anger, irritability, sleeplessness, and anxiety, and significant levels of distress (Demers 2009) and triggers depression, anxiety, decreased marital satisfaction and stress among the wives of the military personnel and this may even lead to somatization. Therefore the present study establishes the correlation between the psychological well-being and physical health of the wives of Indian soldiers and intend to find how different dimensions of each variable influences each other showing the interaction of the dimensions of psychological wellbeing and physical health. Total 300 spouses were selected as respondents. Correlation analysis was used as statistical tool. The results of the analysis show significant and positive correlation between the psychological well-being and physical health.

Keywords: Deployed, Non-Deployed, Psychological-Wellbeing, Stress, Mental Health

Today every Indian citizen is well versed with the tension prevalent between India and Pakistan regarding the years old Kashmir issue. Recently the relations between the two countries have become even worse after the 'Uri Attack' by the terrorists followed by the 'Surgical Strike' done by Indian army. Because of series of encounters and attacks from the side of both the countries so many soldiers martyred their lives to safeguard their nation's security and pride. What the families (especially spouses) of the martyred soldiers have been through are beyond our imagination. These conditions bring a great challenge to the families of the soldiers who are deployed to high insurgency areas or to the areas of hard climatic conditions. The stressors are not only present during the periods of deployments but could also be present during the periods

\footnotetext{
${ }^{1}$ Phd Research Scholar, Deptt of Home Science D.S.B Campus, Kumaon University, Nainital, India

${ }^{2}$ Professor, HOD of Dept. of Home Science D.S.B Campus, Kumaon University, Nainital, India

*Responding Author
}

Received: February 10, 2017; Revision Received: February 23, 2017; Accepted: February 28, 2017

(C) 2017 Prachi B, Pande L; licensee IJIP. This is an Open Access Research distributed under the terms of the Creative Commons Attribution License (www.creativecommons.org/licenses/by/2.0), which permits unrestricted use, distribution, and reproduction in any Medium, provided the original work is properly cited. 


\section{Psychological Well-Being as a Correlate of Physical Well-Being among the Spouses of Indian Armed Force Personnel}

of non-deployments as apart from deployments other activities like frequent relocation from one military station to another, regular moves, short duration stay in one location and dual parenting roles that are projected onto the spouse, make it hard for the spouses who are well qualified, to maintain a stable career leaving them mentally as well as physically fatigued. Military wives also suffer from considerable unemployment, underemployment and low earnings Jacquelyn $\mathbf{S}$ (1990). Army wives are completely supportive of their husband's military career and subordinate their own career development to that of their husbands, this attitude is changing, especially among younger, highly educated (Braddy, 1988).Aspects of the military lifestyle such as frequent relocations explain many of the employment outcomes observed among wives of military personnel. It appears that consideration of the spouse's career is becoming more important in retention decision making in military families.

These situations trigger depression, anxiety, decreased marital satisfaction and stress among the wives of the military personnel that hampers overall well being and may even lead to somatization. Psychological distress that spouse of military soldiers develops with time that include mental states of depression and anxiety and gradually these mental states may lead to physical symptoms like high blood pressure, hypertension and even more worse forms of somatization such as cardiovascular diseases, diabetes and atherosclerosis etc. may arise as a result completely ruining the physical heath of the person. Physical health is important for overall well-being and is the most visible of the various dimensions of health, which also include social, intellectual, emotional, spiritual and environmental health. Health and wellness play a vital role in encouraging individuals to engage with a wide range of activities that could contribute to the development and growth of individuals at every stage of life. Thus, health and wellness also provides internal and external resources to individuals involved and develop a healthy life (Donatelle 2001).Therefore if physical health is jeopardized then it is ultimately going to hamper the overall well being of the individual and ultimately its impact is seen in the society. The relationship between health and wellbeing is not just one-way. Health influences wellbeing and wellbeing itself influences health. Positive wellbeing is related to physical health, aspects of wellbeing such as happiness and optimism are related to longer life, decreased risk of illness and to increased resistance to illness (Lyubomirsky et al 2005 and Veenhoven 2008).

\section{MATERIAL AND METHODS}

Women of reproductive age group of 18 to 45 years were the target of the study. Five regiments posted in Suratgrah military station Rajasthan, was selected by random sampling 50 women from each group (deployed and non-deployed) was selected based on the selected criteria i.e. age, husband's rank and husband's deployment and non-deployment. Therefore comprising a sample of 300 spouses (100 officers' spouses,100 JCOs' spouses and 100 ORs' spouses).Assessment of psychological well-being was done by standardized scale developed by Sisodia and Bhatnagar (2013). The scale assesses psychological wellbeing in 5 areas that includes Satisfaction,

(C) The International Journal of Indian Psychology, ISSN 2348-5396 (e)| ISSN: 2349-3429 (p) | 168 
Efficiency, Sociability, Mental Health and Interpersonal Relation. Physical health was assessed using self developed and statistically pre-tested physical health scale. The scale assesses physical well-being in 4 areas that include nutritional status, micronutrient deficiency status, general physical health and lifestyle.

\section{RESULTS AND DISCUSSION}

Table 4.7.3 Correlation of different aspects of psychological well being and physical health of total respondents

\begin{tabular}{|c|c|c|c|c|c|c|}
\hline \multirow{2}{*}{$\begin{array}{l}\text { Physical } \\
\text { health of the } \\
\text { respondents }\end{array}$} & \multicolumn{6}{|c|}{ Psychological well being of the respondents } \\
\hline & $\begin{array}{c}\text { Life } \\
\text { satisfaction }\end{array}$ & Efficiency & Sociability & $\begin{array}{l}\text { Mental } \\
\text { health }\end{array}$ & $\begin{array}{c}\text { Interpersonal } \\
\text { relationship }\end{array}$ & Total \\
\hline $\begin{array}{l}\text { Nutritional } \\
\text { Status }\end{array}$ & 0.179 & $0.430 * *$ & 0.116 & $0.272^{* *}$ & 0.398 & $0.303^{* *}$ \\
\hline $\begin{array}{l}\text { Micronutrient } \\
\text { Deficiency }\end{array}$ & $0.321 * *$ & $0.370 * *$ & 0.118 & $0.327^{* *}$ & $0.379 * *$ & $0.382^{* *}$ \\
\hline $\begin{array}{c}\text { General } \\
\text { health status }\end{array}$ & 0.106 & $0.224 *$ & 0.144 & $0.135^{* *}$ & 0.129 & 0.121 \\
\hline Lifestyle & $0.283^{* *}$ & $0.271^{* *}$ & 0.100 & $0.238^{* *}$ & 0.241* & $0.296 * *$ \\
\hline $\begin{array}{l}\text { Total Physical } \\
\text { Health }\end{array}$ & $0.337 * *$ & $0.439 * *$ & 0.128 & $0.331^{* *}$ & 0.387 & $0.375^{* *}$ \\
\hline
\end{tabular}

\section{1: Correlation of different aspects of psychological well being and physical health of total respondents}

The correlation of different aspects of psychological well-being and physical health of total respondents (spouses of Indian military personnel) is depicted in the table 1.The co-relational analysis of the dimensions of physical health and psychological well-being brings out the fact that nutritional status( $\mathrm{r}=0.303 ; \mathrm{p}=0.01$ ), micronutrient deficiency status( $\mathrm{r}=0.382 ; \mathrm{p}=0.01)$,lifestyle $(\mathrm{r}=0.296 ; \mathrm{p}=0.01)$ and overall physical health $(\mathrm{r}=0.375 ; \mathrm{p}=0.05)$ was positively and significantly correlated with overall psychological well-being of the spouses of Indian military personnel. As far as the interaction of the components of physical health and psychological well-being is concerned it was observed that nutritional status had a statistically significant and positive correlation with efficiency $(\mathrm{r}=0.430 ; \mathrm{p}=0.01)$ and mental health $(\mathrm{r}=0.272 ; \mathrm{p}=0.05)$ however it also had a positive correlation with life satisfaction, sociability and interrelationship but the correlation was statistically non-significant. Micronutrient status was found to have a positive and statistically significant correlation with life satisfaction $(\mathrm{r}=0.321 ; \mathrm{p}=0.01)$, efficiency $(r=0.370 ; p=0.01)$, mental-health $(r=0.327 ; p=0.01)$ and inter relationship $(r=0.379 ; p=0.01)$ but had non-significant correlation with sociability but the direction of correlation positive. Next dimension i.e. general physical health status was found having a positive and statistically significant correlation with efficiency $(r=0.236 ; p=0.05)$ and mental health $(r=0.236 ; p=0.05)$ which is also found by Aromaa et al (1994) that the risk of CVD death and coronary death was elevated in depressed persons in a study to review the associations between depression and

(c) The International Journal of Indian Psychology, ISSN 2348-5396 (e)| ISSN: 2349-3429 (p) | 169 


\section{Psychological Well-Being as a Correlate of Physical Well-Being among the Spouses of Indian Armed Force Personnel}

cardiovascular diseases, and positive but non-significant correlation with the rest of the dimensions i.e. life satisfaction, sociability and interpersonal relationships. Lifestyle had a positive correlation with life satisfaction $(r=0.283 ; p=0.01)$, efficiency $(r=0.271 ; p=0.01)$, mental health( $\mathrm{r}=0.238 ; \mathrm{p}=0.01)$ and interpersonal relationship $(\mathrm{r}=0.241 ; \mathrm{p}=0.05)$ and just dimension i.e. sociability had a non-significant correlation with lifestyle though the direction of correlation was positive. Overall physical health was found to be positively correlated with life satisfaction( $r=0.337$; $p=0.05)$, efficiency $(r=0.439 ; p=0.05)$, mental health $(r=0.331 ; p=0.05)$ but non-statistically correlated in a positive direction with sociability and interpersonal relationship.

Finally, correlation analysis revealed the fact that physical health was positively and significantly correlated( $\mathrm{r}=0.375 ; \mathrm{p}=0.05)$ with the psychological wellbeing among the spouses of Indian military personnel that means that physical health gets better with increasing psychological wellbeing and vice versa which is supported by a study conducted by Moussavi et al (2007) who indicated that that depression is an important public-health problem, and one of the leading causes of disease burden worldwide. Depression is often co-morbid with other chronic diseases and can worsen their associated health outcomes. Depression produces the greatest decrement in health compared with the chronic diseases angina, arthritis, asthma, and diabetes. The co-morbid state of depression incrementally worsens health compared with depression alone, with any of the chronic diseases alone, and with any combination of chronic diseases without depression.

\section{CONCLUSION}

The present study establishes the correlation between the dimension of psychological well-being and physical well-being. In view of the above discussion it could be inferred that psychological well being and physical health go hand in hand, to stay physically fit it is very much important that one must be in a state of psychological well being not in the state of psychological distress. The results conclude the fact that overall psychological well-being and all the dimensions of psychological well-being except general physical well-being is significantly and positively correlated with the dimensions of physical well-being. This proves the fact that different phases of deployment (pre-deployment and post-deployment) shatters a women's psychological wellbeing due to many contributing factors like loneliness, fear related husband's safety, anticipation of work load, anxiety etc that hampers her physical well-being to a prominent extent. Therefore proper counseling centers and more facilities should be extended to this section of women for their better psychological and physical well-being.

\section{Acknowledgments}

The author appreciates all those who participated in the study and helped to facilitate the research process.

Conflict of Interests: The author declared no conflict of interests. 


\section{REFERENCES}

Aromaa A, Raitasalo R, Reunanen R, Impivaara O, Heliovaara M, Knekt P, Lehtinet V ,M. Joukamaa M, Maatela J(1994) Depression and cardiovascular diseases. Acta Psychiatria scandinavica. 89(3) 77-82.

Braddy, B. A. (In preparation). Exploratory discussions of spouse employment issues.(Research Product 90-06). Alexandria, VA: U.S. Army Research Institute for the Behavioral and Social Sciences.

Demers A (2008) The war at home: Consequences of loving a veteran of the Iraq and Afghanistan Wars: Intr J Med Health. 6(1):44

Donatelle 2001. Health: the basics. 4th ed. Boston:Allyn \& Bacon

Jacquelyn Scarville (1990) U.S. Army Research Institute N for the Behavioral and Social Sciences Research Report 1555 Spouse Employment in the Army: Research Findings DTIC ELEC T ED March 1990

Lyubomirsky, S., King, L. \& Diener, E. (2005). The benefits of frequent positive affect: Does happiness lead to success? Psychological Bulletin. 131-6, 803-855.

Moussavi S, Chatterji S, Verdes E, Tandon A, Patel V and Ustun B (2007) Depression, chronic diseases, and decrements in health: results from the World Health Surveys. The Lancet.370:851-58.

Sisodia D S and Chaudhary P (2005) Psychological well-being Scale. National psychological Coorporation, Agra.

Veenhoven, R. (2008) Healthy happiness: Effects of happiness on physical health and the consequences for preventive health care. $J$ happiness studies. 9, 3, 449-469.

How to cite this article: Prachi B, Pande L (2017), Psychological Well-Being as a Correlate of Physical Well-Being among the Spouses of Indian Armed Force Personnel, International Journal of Indian Psychology, Volume 4, Issue 2, No. 92, ISSN:2348-5396 (e), ISSN:2349-3429 (p), DIP:18.01.119/20170402, ISBN:978-1-365-78192-6 